\title{
Detection of Hearing Loss in Audiological Frequencies from Transient Evoked Otoacoustic Emissions
}

\author{
Artūras JANUŠAUSKAS ${ }^{1}$, Vaidotas MAROZAS ${ }^{1}$, \\ Arūnas LUKOŠEVIČIUS ${ }^{1}$, Leif SÖRNMO ${ }^{2}$ \\ ${ }^{1}$ Biomedical Engineering Institute, Kaunas University of Technology \\ Studentu 65, LT-51369 Kaunas, Lithuania \\ ${ }^{2}$ Signal Processing Group, Lund University, Lund, Sweden \\ e-mail: artjanu@ktu.lt
}

Received: July 2009; accepted: March 2010

\begin{abstract}
Transient evoked otoacoustic emissions (TEOAEs) have been analyzed for objective assessment of hearing function and monitoring of the influence of noise exposure and ototoxic drugs. This paper presents a novel application of the Hilbert-Huang transform (HHT) for detection and time-frequency mapping of TEOAEs. Since the HHT does not distinguish between signal and noise, it is combined with ensemble correlation in order to extract signal information in intervals with correlated activity. High resolution time-frequency mapping could predict $30 \mathrm{~dB}_{\mathrm{HL}}$, or higher hearing loss, at different audiological frequencies in $63-90 \%$ of the cases and normal hearing in $75-90 \%$ of the cases. The proposed method offers TEOAE time-frequency mapping by constraining the analysis to regions with high signal-to-noise ratios. The results suggest that the HHT is suitable for hearing loss detection at individual frequencies and characterization of the fine structures of TEOAEs.
\end{abstract}

Keywords: signal processing, empirical mode decomposition, Hilbert transform, time-frequency mapping, objective hearing level estimation, otoacoustic emissions.

\section{Introduction}

Transient evoked otoacoustic emissions (OAEs) are tiny signals recorded in the outer ear canal in response to acoustic stimulus of short duration. Different studies have shown that TEOAEs can be produced in subjects with mean hearing levels better than $20-40 \mathrm{~dB}_{\mathrm{HL}}$ (Prieve, 1996; Stenklev et al., 2003; Collet et al., 1991; Torre et al., 2003; Gorga et al., 2003; Dietl et al., 2004). The response of the ear is usually recorded 2.5-20 ms after the stimulus. The emissions contain information about the cochlea since their presence indicates that the preneural cochlear receptor and middle ear mechanisms respond normally to sound (Kemp et al., 1990). Since TEOAEs reflect cochlea condition by their absence for a hearing loss of approximately $30 \mathrm{~dB}_{\mathrm{HL}}$ or more, they have the potential to be used for screening of hearing function (Sokol et al., 2002), monitoring of the influence of noise 
exposure (Smeatham, 2002) and the influence of ototoxic drugs on hearing (McFadden et al., 1994).

The TEOAE is a highly nonstationary signal whose frequency content varies considerably over time, characterized by early high frequency components which are followed by low frequency components with longer duration (Sokol et al., 2002; Avan et al., 1993; Tognola et al., 1996; Janušauskas et al., 1999). This particular time-frequency structure may be explained by the tonotopic frequency analysis of the cochlea. The short-term Fourier transform, the wavelet transform, the Wigner-Ville and the ChoiWilliams transforms have all been used in various studies for time-frequency analysis of TEOAEs (Janušauskas et al., 2002; Wit et al., 1994; Cheng, 1995). Empirical mode decomposition combined with the Hilbert transform, sometimes referred to as the HilbertHuang transform (Huang et al., 1998), is yet another approach which may provide more detailed time-frequency information than the above-mentioned ones (Huang et al., 1998, 2003). This transform decomposes the signal into narrowband components, called intrinsic mode functions (IMFs), for which the Hilbert spectrum is computed. Empirical mode decomposition has been successfully employed in various applications where nonstationary signal analysis is called for (Huang et al. 2003; Echavaria et al., 2001; Andrade et al., 2003; Lemay et al., 2006; Blanco-Velasco et al., 2008).

Several attempts have been made to estimate the pure tone hearing threshold from TEOAEs (Collet et al., 1991; Torre et al., 2003; Gorga et al., 2003; Wagner et al., 1999; Prieve et al., 1993). An early study showed that significant correlation exists between the presence of OAEs in specific frequency bands and the hearing threshold for these bands (Collet et al., 1991). This observation was later confirmed in Gorga et al. (2003), Dietl et al. (2004), Wagner et al. (1999) where TEOAEs as well as distortion product OAEs were considered. A significantly lower correlation was found between the hearing threshold and the presence of OAEs at lower frequencies due to poor signal-to-noise ratio (SNR), resulting in poor specificity at $500 \mathrm{~Hz}$ and $1 \mathrm{kHz}$ (Torre et al., 2003). Similar results were obtained using TEOAEs for hearing threshold estimation, confirming that the highest correlation between TEOAEs and hearing threshold is found around $2 \mathrm{kHz}$ and the lowest correlation at lower frequencies (Dietl et al., 2004; Wagner et al., 1999; Prieve et al., 1993). Possibility to predict high frequency hearing loss was also discussed in our previous article (Janušauskas et al., 2006) and this research extends, improves previously presented method, and also provides additional data and numerical results.

The aim of the present study is twofold: to develop a method for detection and characterization of TEOAE time-frequency properties and to determine the correlation between the presence of TEOAEs and pure tone hearing threshold at that frequency. Sections 2 and 3 describe the signal processing techniques employed and the TEOAE database subjected to analysis, respectively. The results are presented in Section 4 in terms of overall statistics as well as illustrative examples, and is then followed by a discussion in Section 5. 


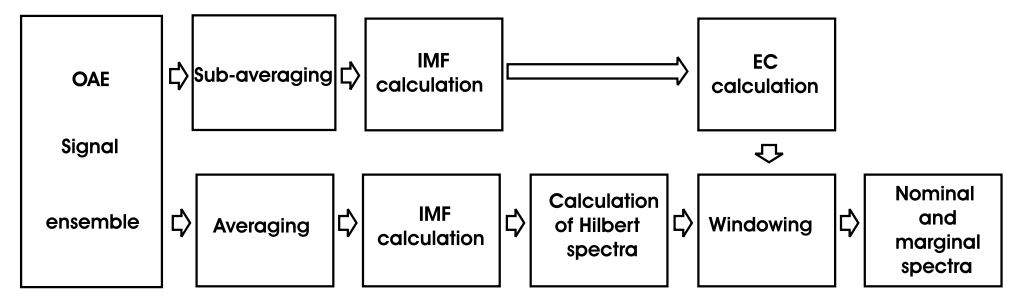

Fig. 1. Block diagram for detection and time-frequency mapping of TEOAE signals.

\section{Methods}

The present method embraces techniques for detection and time-frequency mapping of TEOAE signals. The different signal processing steps are described by the respective block diagrams in Fig. 1.

\subsection{TEOAE Time-Frequency Mapping and Detection}

Time-frequency mapping involves the following signal processing steps. First, the ensemble of TEOAE signals is averaged and decomposed into four IMFs. In this study, the first four IMFs are used for detection since they together cover the frequency range of interest for TEOAEs, i.e., $0.6-6 \mathrm{kHz}$. The remaining IMFs contain low frequency components with negligible energy and are therefore discarded from further analysis. Next, the Hilbert analytical amplitudes and instantaneous frequencies are calculated for each of the IMFs. The nominal Hilbert spectrum is formed by aggregating the instantaneous frequencies and the corresponding amplitudes into $20 \mathrm{~Hz}$ frequency bins; see Appendix for details. Only signal segments weighted with an ensemble correlation that exceeds 0.6 are used for mapping to ensure that spectral components exceeding a certain SNR are only considered. Details regarding ensemble correlation method are presented in previous articles (Atarius et al., 1995; Janušauskas et al., 2002).

The marginal Hilbert spectrum is calculated from the nominal Hilbert spectrum and used to determine the method's ability to detect TEOAEs at specific frequencies and to establish potential relationships between TEOAE presence and hearing level. The detection procedure is based on the assumption that TEOAEs are present when the extracted, high SNR signal exceeds a certain level at the specific frequency: a TEOAE is detected at the frequency $f_{0}$ when the average of the marginal spectrum in the band $f_{0} \pm 5 \%$ exceeds a level corresponding to $0.1 \mathrm{mPa}$.

\subsection{Comparative Detection Parameter}

The performance of the present method was compared to parameter commonly used in clinical studies as a "golden standard", namely, "band reproducibility" (Molini et al., 2004). Band reproducibility is defined as crosscorrelation coefficient computed from two non-overlaping bandpass filtered subaverages at $2.5-20 \mathrm{~ms}$ poststimulus, the filters being centered around $1,2,3$, and $4 \mathrm{kHz}$, with a $1 \mathrm{kHz}$ bandwidth. 


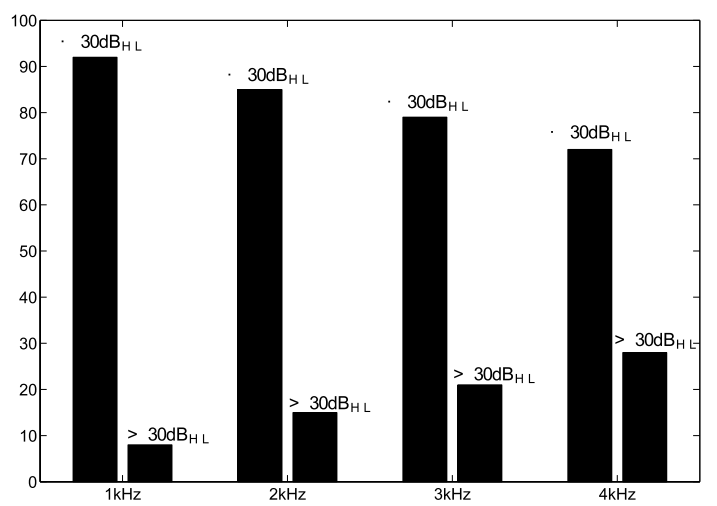

Fig. 2. Distribution of the individual hearing levels in the present database.

\section{Database}

A database of 4989 TEOAE records from the study "Otoacoustic emissions in the general adult population of Nord-Trøndelag, Norway" was analyzed (Engdahl, 2002). The database is considered to be representative of the adult population in this geographical region with respect to hearing loss in the left ear. The database contained 2,175 men and 2,814 women with an average age of 49 years, ranging from 20 to 96 years. Transient evoked OAEs were recorded in an attenuation booth or in a relatively quiet, but not sound-proof, room using the ILO92 OAE recording device (Otodynamics Ltd.). The signals were acquired during $20 \mathrm{~ms}$ at a sampling rate of $25,600 \mathrm{~Hz}$ in the most commonly used "nonlinear" mode of operation and stored as raw data. The acquisition was terminated when the quality of the response met one of the criteria involving TEOAE level, SNR, reproducibility, or noise level (Engdahl, 2002). The health screen also included air conduction, pure tone audiograms recorded by an Interaco ustics AD25 audiometer. Each audiogram was related to a TEOAE record and used to classify it according to hearing threshold.

The audiometric criterion used to separate hearing level at specific frequency as "normal" (NH) from "hearing loss" (HI) was defined by a pure tone hearing threshold above $30 \mathrm{~dB}_{\mathrm{HL}}$. The distribution of individual hearing levels for the database are displayed in Fig. 2. In order to assess the ability of TEOAEs to predict hearing loss at specific frequencies, a hearing threshold lower or equal than $30 \mathrm{~dB}_{\mathrm{HL}}$ is considered as indicative.

\section{Results}

The possibility to predict hearing loss at specific frequencies was investigated. Normal hearing subjects had a richer spectral content than subjects with hearing loss as shown by the examples in Fig. 3. In Fig. 3 upper panel, the TEOAE spectrum had high frequency components up to 6-7 ms poststimulus, while components in the interval $0.6-2 \mathrm{kHz}$ were 

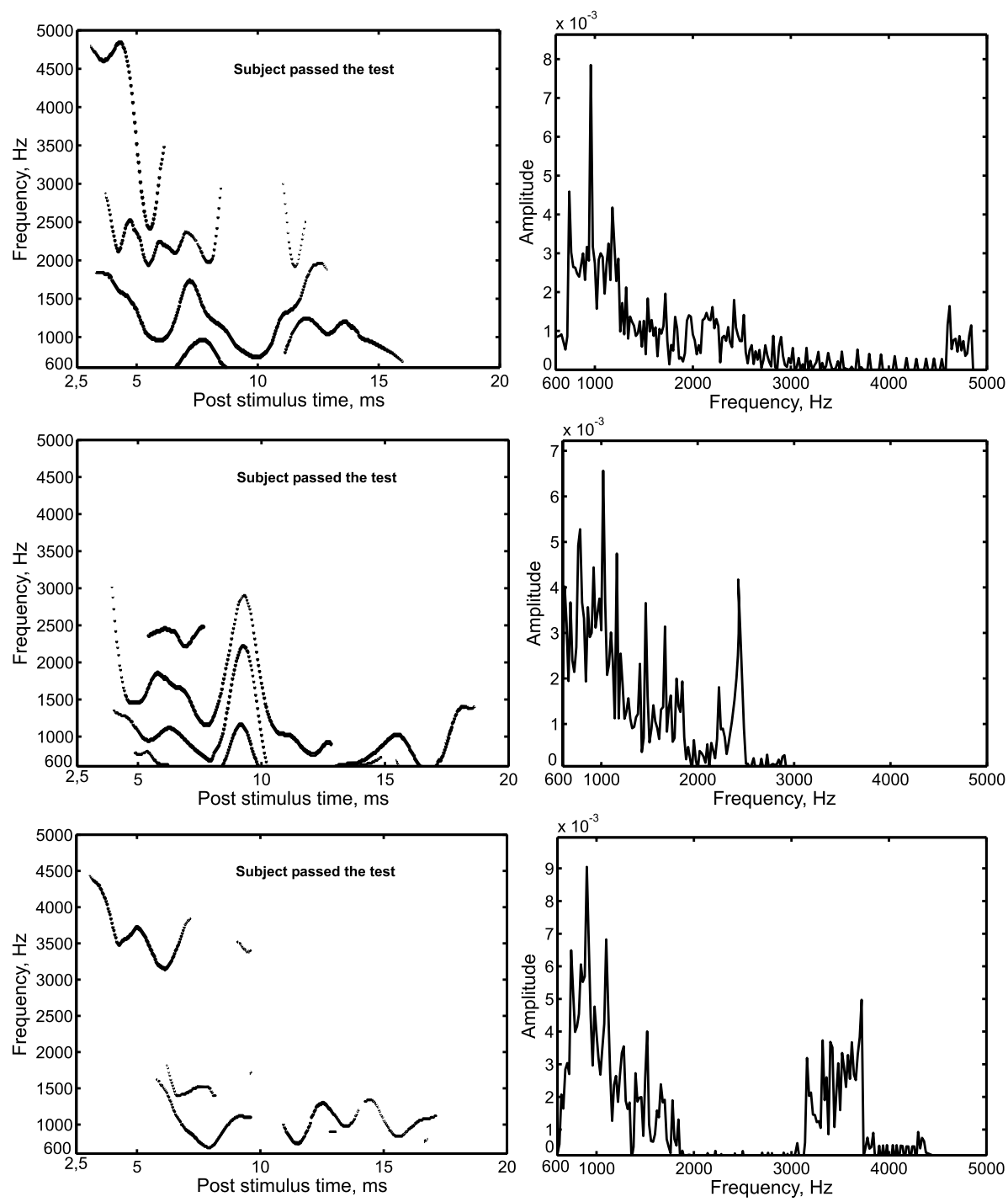

Fig. 3. Nominal (left) and marginal (right) Hilbert spectra for a subjects: top - normal hearing, middle - with sloping high frequency hearing loss, lowest - with hearing loss at certain frequencies in the audiological range.

present throughout most of the record. In Fig. 3 middle panel, a subject with a high frequency hearing loss exhibited almost no high frequency components, while the lower frequencies were present throughout the record. This finding corresponded well to the subject's audiogram with hearing levels better than $30 \mathrm{~dB}_{\mathrm{HL}}$ at frequencies up to $2 \mathrm{kHz}$, while lower than $35 \mathrm{~dB}_{\mathrm{HL}}$ at higher frequencies.

In a number of cases the lack of TEOAEs at certain frequencies predicted hearing levels worse than $30 \mathrm{~dB}_{\mathrm{HL}}$ at the same frequencies even if the hearing threshold was better 
Table 1

Percentage of correctly detected $30 \mathrm{~dB}_{\mathrm{HL}}$ hearing thresholds.

\begin{tabular}{llllll}
\hline Subjects & Method & $1 \mathrm{kHz}$ & $2 \mathrm{kHz}$ & $3 \mathrm{kHz}$ & $4 \mathrm{kHz}$ \\
\hline Normal hearing & HHT method & $90 \%$ & $84 \%$ & $75 \%$ & $75 \%$ \\
& Band reproducibility & $64 \%$ & $77 \%$ & $73 \%$ & $71 \%$ \\
\multirow{2}{*}{ Hearing loss } & HHT method & $63 \%$ & $82 \%$ & $90 \%$ & $89 \%$ \\
& Band reproducibility & $90 \%$ & $82 \%$ & $90 \%$ & $86 \%$ \\
\hline
\end{tabular}

at all other frequencies, see Fig. 3, bottom. In this case TEOAEs were recorded from a subject with the following audiogram: $5 \mathrm{~dB}_{\mathrm{HL}}$ at $500 \mathrm{~Hz}, 5 \mathrm{~dB}_{\mathrm{HL}}$ at $1 \mathrm{kHz}, 35 \mathrm{~dB}_{\mathrm{HL}}$ at $2 \mathrm{kHz}, 25 \mathrm{~dB}_{\mathrm{HL}}$ at $3 \mathrm{kHz}$, and $25 \mathrm{~dB}_{\mathrm{HL}}$ at $4 \mathrm{kHz}$. Analysis of the emissions shows that there is a lack of signal components in the interval $1.9-3 \mathrm{kHz}$, see Fig. 3 middle panel.

Next, we present the results on how well the proposed method can predict individual hearing levels better than $30 \mathrm{~dB}_{\mathrm{HL}}$, see Table 1. The sensitivity of the HHT method was similar or better for 2,3 , and $4 \mathrm{kHz}$ when compared to that of band reproducibility, but considerably lower at $1 \mathrm{kHz}$. The specificity of the HHT method was better for all frequencies.

\section{Discussion and Conclusions}

Time-frequency methods is widely used for biomedical signal processing in nowadays (Mačiulis et al., 2009; Janušauskas et al., 2006; Dietl et al., 2004). Automatic methods for clinical decision support are also continually growing in tact with the new developments in signal processing which are often based on heuristic approaches (Dzemyda et al., 2009; Lemay et al., 2006; Janušauskas et al., 2001). In this article we presented a novel Hilbert-Huang transform based method which is in its kernel heuristic for OAEs time-frequency characterization and automatic detection of OAEs presence in audiometric frequencies.

There is a common opinion that significant correlation is difficult to achieve, if not impossible, between TEOAE levels and audiometric thresholds and a quantitative prediction of hearing thresholds for individual listeners based on click evoked OAEs. In our study, however, we have made an attempt to determine to what degree modern signal processing methods can be useful for individual hearing level detection and to what degree OAE time-frequency mapping can predict audiogram shape.

Good detection rates as well as capability to extract time-frequency features corresponding to other audiological data (cf. Fig. 3 and Table 1) suggest that the present method can extract features from the recorded signal which correlate quite well with audiogram shape. The poor sensitivity observed at $1 \mathrm{kHz}$ has been confirmed in previous studies (Gorga et al., 2003; Torre et al., 2003; Janušauskas et al., 2001).

It is difficult to say whether the reasons to the incorrectly identified cases are due to physiological or methodological limitations. Poorer $\mathrm{HI}$ detection at $1 \mathrm{kHz}$ may be 
explained by higher probability of correlated noise, few subjects, or, possibly, incorrect audiograms. Poorer $\mathrm{NH}$ detection at higher frequencies may be related to lower energy of such components in the analysis window and the use of the same TEOAE level detection threshold for all frequencies. Despite this, the HHT method suggests that emissions are present at frequencies where hearing thresholds are better than $30-40 \mathrm{~dB}_{\mathrm{HL}}$, likely to be found in good quality data; this observation applies primarily to hearing impairment of cochlear origin.

The frequency resolution of the HHT method was set to $20 \mathrm{~Hz}$ and included only signal components that exceeded a level corresponding to $0.1 \mathrm{mPa}$. The frequency resolution was chosen as a compromise between extraction of signal properties, computational complexity, and trend estimation. As previously noted, the HHT method produces more detailed time-frequency maps than does, e.g., the continuous wavelet transform (CWT; Roulier et al., 2005). Differences in performance between the CWT and HHT are illustrated in Fig. 4. Using the HHT method, the spectrum is displayed before and after application of ensemble correlation, see Figs. 4(a) and 4(b), respectively. The timefrequency representation of the CWT is displayed in Fig. 4(c). Signals recorded from normal hearing subjects have typically a boomerang-like shape of the time-frequency distribution, whereas subjects with high frequency hearing loss have a more flattened distribut ion. Using the CWT, the energy of signal components are distributed over the different scales, thus reducing the possibility to capture low level components. From the example in Fig. 4, it is obvious that the HHT method extracts finer signal details from the intrinsic mode functions, whereas the CWT does not achieve the same resolution of the signal. Considering that the present method makes no a priori assumptions on signal properties, it seems highly suitable for analysis of neonatal and pediatric data where latency patterns differ from those observed in adults (Sokol et al., 2002; Zimatore et al., 2002).

In this study, it was assumed that subjects with hearing level of $30 \mathrm{~dB}_{\mathrm{HL}}$ and better at specific frequency exhibit TEOAEs while with hearing level worse than $30 \mathrm{~dB}_{\mathrm{HL}}$ do not. This assumption is obviously quite strong since, even if TEOAEs can reasonably well differentiate between populations of $\mathrm{NH}$ and $\mathrm{HI}$ subjects, the transition between $\mathrm{NH}$ and $\mathrm{HI}$ subjects is not very steep and the variability across subjects is very large. Otoacoustic emissions may or may not be generated in the border zone from 20 to $40 \mathrm{~dB}_{\mathrm{HL}}$. For the case of retrocochlear hearing loss, TEOAEs can also be recorded although a hearing loss worse than $30 \mathrm{~dB}_{\mathrm{HL}}$ was found by audiometry (Vatovec, 2000).

\section{Appendix}

\section{A.1. Empirical Mode Decomposition}

Empirical mode decomposition is particularly suitable for analysis of nonstationary signals in which the signal is decomposed into oscillating components (IMFs) suitable for instantaneous frequency calculation using the Hilbert transform (Huang et al., 1998). The 

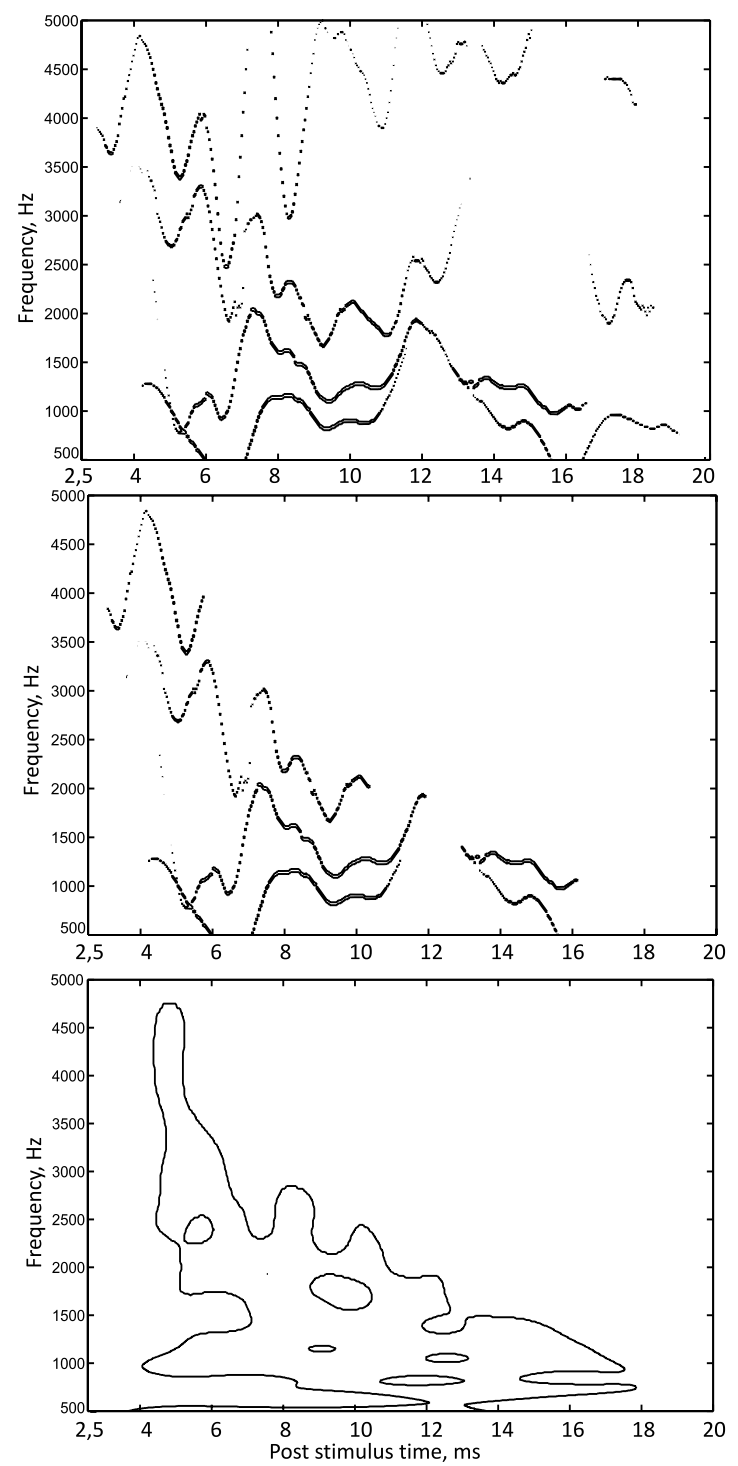

Fig. 4. Time-frequency spectra resulting from the HHT, before (upper diagram) and after (middle diagram) application of ensemble correlation. The CWT is computed using the Morlet wavelet (lower diagram). The frequency resolution of the HHT is set to $20 \mathrm{~Hz}$. The contour lines represent $10 \%$ of the maximum amplitude.

IMFs result from an iterative procedure consisting of extrema identification and "sifting" described below. The observed signal $s(t)$ constitutes the input to sifting, and $s_{i, k}(t)$ defines a component of the sifting process $(i$ denotes iteration number and $j$ sifting component); the procedure is initialized with $s_{1,1}(t)=s(t)$. The following steps define sifting: 

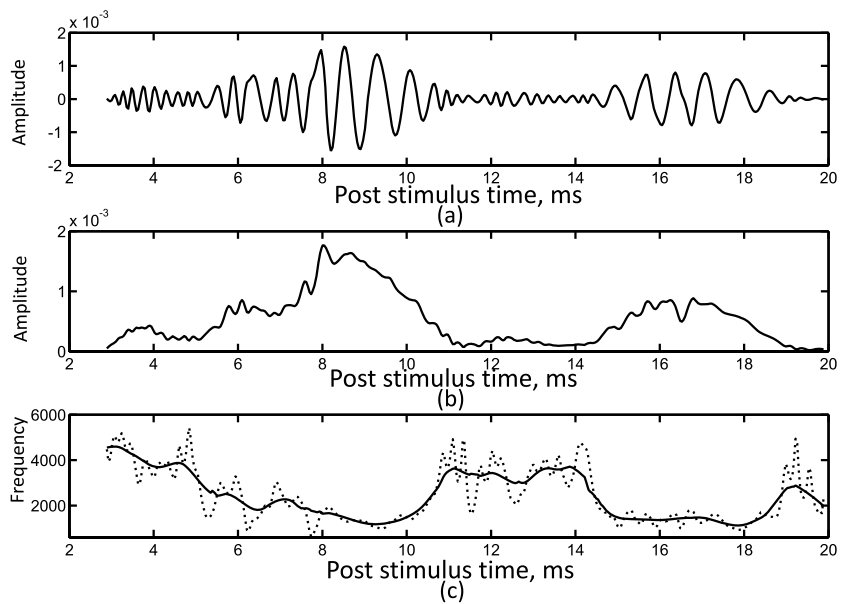

Fig. 5. Illustration of empirical mode decomposition. (a) Intrinsic mode function, (b) its analytical amplitude, and (c) the instantaneous frequency before (dotted line) and after (bold line) smoothing.

1. The local minima and maxima of $s_{i, k}(t)$ are determined.

2. The lower and upper envelopes are determined by interpolation of $s_{i, k}(t)$ between the local maxima and minima, respectively.

3. The mean value $m_{i, k}(t)$ of the resulting upper and lower envelopes is computed and subtracted from $s_{i, k}(t)$ so that the next component of sifting is defined by

$$
s_{i, k+1}(t)=s_{i, k}(t)-m_{i, k}(t) .
$$

4. The component $s_{i, k+1}(t)$ is checked against the following IMF conditions and, if not met, sifting continues (Steps 1 through 3 is repeated with $k=k+1$ ). Condition 1. An IMF is, by definition, symmetric in time and has a number of extrema and zero crossings which must be equal or, at most, differ by one. Condition 2 . The mean value of the envelopes, defined by the local maxima and local minima, must be zero at all times.

5. The above steps are repeated until the two conditions are met; the resulting IMF is denoted $c_{i}(t)$. To speed up the procedure, the second IMF condition is relaxed when the standard deviation $\sigma_{s}$,

$$
\sigma_{s}=\sum_{t=0}^{T}\left[\frac{\left|s_{i, k-1}(t)-s_{i, k}(t)\right|^{2}}{s_{i, k-1}^{2}(t)}\right]
$$

is less than 0.2. The parameter $T$ denotes the signal length.

The next sifting process starts after subtraction of $c_{i}(t)$ from signal $s_{i, 1}(t)$ so that the resulting signal $r_{i}(t)$ is the input to the successive sifting process:

$$
r_{i}(t)=s_{i, 1}(t)-c_{i}(t), \quad s_{i+1,1}(t)=r_{i}(t) .
$$



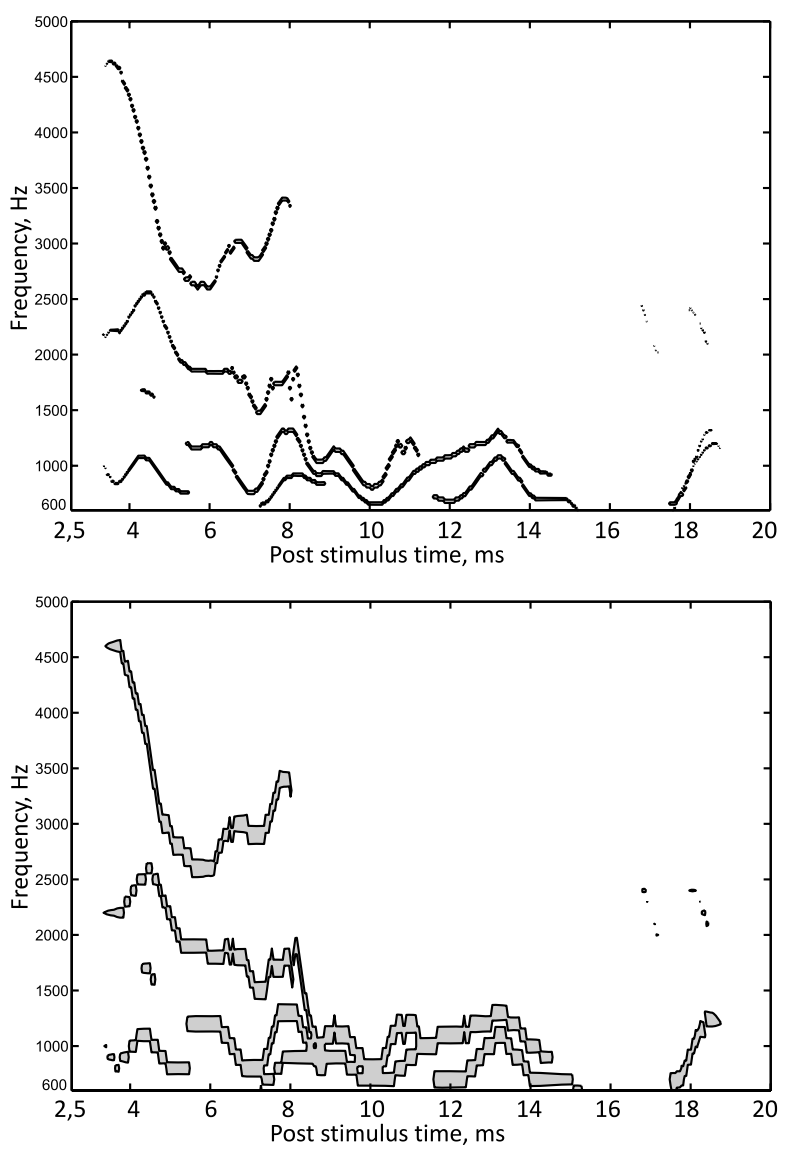

Fig. 6. Illustration of the Hilbert nominal spectrum using different frequency resolutions, $20 \mathrm{~Hz}$ (top) and $100 \mathrm{~Hz}$ (bottom).

This process is repeated until the residual $r_{N}(t)$ has less than 3 extrema, which means that all IMFs have been extracted. The observed signal $s(t)$ can be expressed as a sum of IMFs and the residual $r_{N}(t)$,

$$
s(t)=\sum_{i=1}^{N} c_{i}(t)+r_{N}(t) .
$$

\section{A.2. Time-Frequency Representation with Hilbert Spectrum}

The Hilbert spectrum and the instantaneous frequency are particularly meaningful when $s(t)$ is a monocomponent signal, described by a single frequency component at any time instant (Huang et al., 1998; Kizhner et al., 2004). Intrinsic mode functions satisfy this condition by calculation of the Hilbert amplitudes and instantaneous frequencies for each individual IMF, producing an analytical time-frequency representation of the sig- 
nal. The signal $s(t)$ may be expressed in terms of the analytical amplitude $A_{i}(t)$ and instantaneous frequency $w_{i}(t)$ (Huang et al., 1998; Kizhner et al., 2004):

$$
\begin{aligned}
& s(t)=\Re\left\{\sum_{i=1}^{N} A_{i}(t) e^{j \int w_{i}(t) d t}\right\}, \\
& w_{i}(t)=\frac{d \theta_{i}(t)}{d t}
\end{aligned}
$$

where $A_{i}(t)$ and $\theta_{i}(t)$ denote the Hilbert transform modulus and phase, respectively, which result from the Hilbert transform of $c_{i}(t)$, see Fig. 5. Smoothing of the instantaneous frequency is often applied to produce trends of the time-frequency information. In this study, so-called robust, locally weighted smoothing is employed which can handle the presence of outliers in the signal (Cleveland, 1979).

For all IMFs, $A_{i}(t)$ and $w_{i}(t)$ can be represented in a 3D-plot where the amplitude is contoured in the time-frequency domain. The resulting time-frequency distribution is called a nominal Hilbert spectrum, constructed by aggregating instantaneous frequencies and corresponding amplitudes of IMFs into defined frequency bins, and displayed in a 3D-diagram with time, frequency, and Hilbert amplitude defining the axes. The Hilbert amplitude represents the square root of the local signal energy. The frequency bins may be freely chosen with respect to resolution. Fig. 6 shows the Hilbert nominal spectra of a TEOAE signal.

\section{References}

Andrade, A.O., Kyberd, P.J., Taffler, S.D. (2003). A novel spectral representation of electromyographics signals. In: Proceedings of 25th Int. Conf. IEEE EMBS, Cancun, Mexico, pp. 2598-2601.

Atarius, R., Sörnmo, L. (1995). Signal-to-noise ratio enhancement of cardiac late potentials using ensemble correlation. IEEE Trans. Biomed. Eng., 42(11), 1132-1137.

Avan, P., Bonfils, P., Loth, D., Wit, H.P. (1993). Temporal patterns of transient-evoked otoacoustic emissions in normal and impaired cochlea. Hear. Res., 70, 109-120.

Blanco-Velasco, M., Weng, B., Barner, K. (2008). ECG signal denoising and baseline wander correction based on the empirical mode decomposition. Comput. Biol. Med., 38(1), 1-13.

Cheng, J. (1995). Time-frequency analysis of transient evoked otoacoustic emissions via smoothed Wigner distribution. Scand. Audiol., 24, 91-96.

Cleveland, W.S. (1979). Robust locally weighted regression and smoothing scatterplots. J. Acoust. Assoc., 74, 829-836.

Collet, L., Veuillet, E., Chanal, J.M., Morgon, A. (1991). Evoked otoacoustic emissions: correlates between spectrum analysis and audiogram. Audiology, 30, 164-172.

Dietl, H., Weiss, S. (2004). Detection of cochlear hearing loss applying wavelet packets and support vector machines. In: Proceedings of the 38th Asilomar Conf. on Signals, Systems and Computers, Pacific Grove, CA, pp. 1575-1579.

Dzemyda, G., Sakalauskas, L. (2009). Optimization and knowledge based technologies. Informatica, 20(2), $165-172$.

Echeveria, J.C., Crowe J.A., Woolfson, M.S., Hayes-Gill, B.R. (2001). Application of empirical mode decomposition to heart rate variability analysis. Med. Biol. Eng. Comput., 39, 471-479. 
Engdahl B. (2002). Otoacoustic emissions in the general adult population of Nord-Trøndelag, Norway: I. Distributions by age, gender, and ear side. Int. J. Audiol., 41(1), 64-77.

Gorga, M.P., Neely, S.T., Dorn, P.A., Hoover, B.M. (2003). Further efforts to predict pure-tone thresholds from distortion product otoacoustic emission input/ouput functions. J. Acoust. Soc. Am., 113(6), 3275-3284.

Huang, N., Shen, Z., Long, S., Wu, M., Shih, H., Zheng, Q., Yen, N., Tung, C., Liu, H. (1998). The empirical mode decomposition and Hilbert spectrum for nonlinear and non-stationary time series analysis. Proc. R. Soc. London, 454, 903-995.

Huang, N., Wu, M.L., Qu, W., Long, S.R., Shen, S., Zhang, J.E. (2003). Applications of Hilbert-Huang transform to non-stationary financial time series analysis. Appl. Stoch. Models Bus. Ind., 19, 245-268.

Janušauskas, A., Engdahl, B., Svensson, O., Sörnmo, L. (1999). Latency of otoacoustics emissions frequency components. Med. Biol. Eng. Comp., 37, Suppl 1, 332-333.

Janušauskas, A., Marozas, V., Engdahl, B., Hoffman, H.J., Svensson, O., Sörnmo, L. (2001). Otoacoustic emissions and improved pass/fall separation using wavelet analysis and time windowing. Med. Biol. Eng. Comput., 39, 134-139.

Janušauskas A., Sörnmo, L., Svensson, O., Engdahl, B. (2002). Detection of transient evoked otoacoustics emissions and design of time windows. IEEE Trans. Biomed. Eng., 49(2), 132-139.

Janušauskas, A., Marozas, V., Lukoševičius, A., Sörnmo, L. (2006). The Hilbert-Huang transform for detection of otoacoustic emissions and time-frequency mapping. Informatica, 17(1), 25-38.

Kemp, D.T., Ryan, S., Bray, P. (1990). A guide to the effective use of otoacoutic emissions. Ear Hear, 11(2), 93-105.

Kizhner, S., Flatley, P., Huang, E.N., Blank, K., Conwell, E. (2004). On the Hilbert-Huang transform data processing system development. In: Proceedings of IEEE Aerospace Conf., pp. 1961-1979.

Lemay, M., Vesin, J.M. (2006). QRST cancellation based on the empirical mode decomposition. Proc. Comput. Cardiol., 33, 561-564.

Mačiulis, A., Paunksnis , A., Barzdžiukas, V., Kriaučiūnienė, L., Buteikienė, D., Puzienė, V. (2009). Digital model of blood circulation analysis system. Informatica, 20(4), 539-554.

McFadden, D., Pasanen, G.E. (1994). Otoacoustic emissions and quinine sulphate. J. Acoust. Soc. Am., 99(5), 3460-3474.

Molini, E., Ricci, G., Baroni, S., Ciorba, A., Belloci, A., Simonelli C. (2004). Indentifying congenital hearing impairment. Personal experience based on selective hearing screening. Acta Otolaryngol. Ital., 24, 109-116.

Prieve, B.A. (1996). Click and tone-burst-evoked otoacoustic emissions in normal and hearing impaired ears. J. Acoust, Soc. Am., 99(5), 3077-3086.

Prieve, B.A., Gorga, P.M., Schimdt, A., Neely, S., Peters, J., Schultes, L., Jesteadt, W. (1993). Analysis of transient-evoked otoacoustic emissions in normal-hearing and hearing-impaired ears. J. Acoust. Soc. Am., 93, 3308-3319.

Roulier, R., Humeau, A., Flatley T.P., Abraham, P. (2005). Comparison between Hilbert-Huang transform and scalogram methods on non-stationary biomedical signals: application to laser Doppler flowmetry recordings. Phys. Med. Biol., 50, 5189-5202.

Smeatham, D. (2002). Noise Levels and Noise Exposure of Workers in Pubs and Clubs - A Review of the Literature. HSE Books, Norwich.

Sokol, J., Hyde, M. (2002). Hearing screening. Pediat. Rev., 23(5), 155-161.

Stenklev, N.C., Laukli, E. (2003). Transient evoked otoacoustic emissions in the elderly. Int. J. Audiol., 42(3), $132-139$.

Tognola, G., Grandori, F., Ravazzani, P. (1996). Latency distribution of click-evoked otoacoustic emissions. In: Proceedings of the 18th Int. Conf. IEEE Eng. Med. Biol., Amsterdam, pp. 1526-1527.

Torre III, P., Cruinckshanks, J.K., Nondahl, D.M., Wiley, T.L. (2003). Distortion product otoacoustic emission response characteristics in older adults. Ear Hear., 24, 20-29.

Vatovec, J. (2000). Otoacoustic emissions in central auditory disorders. Eur. J. Physiol., 439 (Suppl.), R222R224.

Wagner, W., Plinkert, P.K. (1999). The relationship between auditory threshold and evoked otoacoustic emissions. Eur. Arch. Otorhinolaryngol., 256, 177-188.

Wit, H.P., Dijk, P., Avan, P. (1994). Wavelet analysis of real ear and synthesized click evoked otoacoustic emissions. Hear. Res., 73, 141-147.

Zimatore, G., Hatzopoulos, S., Giuliani, A., Martini, A., Colosimo, A. (2002). Comparison of transient otoacoustic emission responses from neonatal and adult ears. J. Appl. Physiol., 92, 2521-2528. 
A. Janušauskas received the MSc and DrSc degrees in electrical and electronics engineering from Kaunas Technology University, Kaunas, Lithuania, in 1996 and 2000, respectively. Since year 2000 he holds a research scientist position at Kaunas Biomedical Engineering Institute. His research interests include biomedical signal processing, detection and time-frequency analysis of otoacoustic emissions, ECG, ICG signal processing, analysis of ultrasonic signals and telemedicine applications.

V. Marozas received his BS in engineering electronics in 1993, MS in metrology and measurements in 1995, and $\mathrm{PhD}$ in electrical and electronics engineering from Kaunas University of Technology in 2000. Since year 2000 he has been employed as a research scientist at the Institute of Biomedical Engineering. His research interests include biomedical signal processing, time-frequency analysis, wavelet analysis and neural networks.

A. Lukoševičius received $\mathrm{DrSc}$ and doctor habilitus degrees in electrical engineering from Kaunas University of Technology (KTU) in 1976 and 1996, respectively. In 19962000 he was in position of a vice-rector for research of KTU. Since 2000 he holds a position of professor and director of Biomedical Engineering Institute of KTU. In 2000 he was awarded by National Science Award. His research interests include biomedical engineering, signal and image processing, ultrasound diagnostics, e-Health and decision support systems.

L. Sörnmo received the MSc and DrSc degrees in electrical engineering from Lund University, Lund, Sweden, in 1978 and 1984, respectively. He held a research position with Department of Clinical Physiology, Lund University, from 1983 to 1995 working with computer-based ECG analysis. Since 1990, he has been at the Signal Processing Group, Department of Electroscience, Lund University, where he now holds a position as a professor in biomedical signal processing. His main research interests include statistical signal processing and modeling of biomedical signals. His current research projects include high-resolution ECG analysis, methods in ischemia monitoring, time-frequency analysis of atrial fibrilation, power efficient signal processing in pacemakers, and detection of otoacoustic emissions. Dr. Sörnmo was on the editorial board of Computers in Biomedical Research from 1997 to 2000. Since 2001, he is an associate editor of IEEE Transactions on Biomedical Engineering. 


\title{
Klausos netekimo atskiruose dažniuose nustatymas iš otoakustinès emisijos signalo
}

\author{
Artūras JANUŠAUSKAS, Vaidotas MAROZAS, Arūnas LUKOŠEVIČIUS, \\ Leif SÖRNMO
}

Straipsnis pratęsia ankstesnius autorių tyrimus impulsu sukeltos otoakustinès emisijos analizès ir jos panaudojimo objektyviems klausos slenksčių nustatymams galimybes. Šiuo metu egzistuoja daug metodų skirtų vidutiniam klausos slenksčiui nustatyti iš impulsu sukeltos otoakustinès emisijos signalo, tačiau vos keletas, tarp jụ ir šių autorių, skirtu ịvertinti audiogramos (klausos jautrumo dažninès charakteristikos) formai. Šis lengviausiai ir greičiausiai padaromas klausos tyrimas praktiškai nèra naudojamas individualiu klausos slenksčiu ar klausos netekimo atskiruose dažniuose nustatymui, spètina dèl signalo ir jo analizės kompleksiškumo ir išankstinès nuostatos, kad signalas iš principo netinkamas šiam tikslui. Straipsnio autoriai, remdamiesi ankstesniu įdirbiu ir naudodami patobulintus, anksčiau pristatytus metodus, visgi bando ištirti klausos netekimo nustatymo atskiruose dažniuose galimybes, naudodami impulsu sukeltos otoakustinès emisijos signalą. Straipsnyje pristatytas tyrimas parodè, kad, naudojant jautrius šiuolaikinius signalo apdorojimo metodus, tokius kaip empirinè modu dekompozicija, Hilberto-Huango transformacija, ansamblio koreliacija, galima su priimtinu patikimumu nustatyti klausos netekimą atskiruose dažniuose. Rezultatai rodo, kad pasiūlyta metodika teisingai identifikavo klausos netekimą 63-90\% (aukštesniuose, nei $1 \mathrm{kHz}$, $82-90 \%$ ) atveju ir 75-90\% geros klausos atveju $1 \mathrm{kHz}, 2 \mathrm{kHz}, 3 \mathrm{kHz}, 4 \mathrm{kHz}$. Rezultatai buvo geresni, lyginant su bene vieninteliu šiam tikslui klinikinejje praktikoje naudojamu metodu. 